\title{
Women's Human Rights in North- East India
}

\author{
Jogesh Das \\ Research Scholar, Department of Political Science, Dibrugarh University
}

\begin{abstract}
About half of the world population is constituted by women, but yet they have not treated equally as men or they have not enjoyed equal rights in the society. Gender differences, customs, traditions, social attitudes etc., are mainly responsible for the inequality between men and women. Women in traditional patriachical society have always been considered as weaker section or inferior section of the society. Today, all the members of the society have an equal right to live, to enjoy equality, to be treated justly and to live in peace. Besides, the Human Rights of women and girl child are an integral part of the universal human rights (1993 World Conference on Human Rights). Thus in this paper, an attempt has been made to conceptualize certain gender specific violation as Human Rights violation in context of North East India. The methodology of this paper is descriptive and required information are collected from different secondary sources like books. research articles, different government documents etc.
\end{abstract}

\section{Introduction}

About half of the world population is constituted by women, but yet they have not treated equally as men or they have not enjoyed equal rights in the society. Gender differences, customs, traditions, social attitudes etc., are mainly responsible for the inequality between men and women. Women in traditional patriachical society have always been considered as weaker section or inferior section of the society. Today, all the members of the society have an equal right to live, to enjoy equality, to be treated justly and to live in peace. Besides, the Human Rights of women and girl child are an integral part of the universal human rights (World Conference on Human Rights, 1993).

\section{A Profile of North East India}

The north-eastern part of India is bounded by China in the north, Bangladesh in the south west, and Bhutan in the north west and Burma in the east. Isolated from the rest of India, both geographically and economically, this region is tenuously linked to the rest of the country by a narrow corridor running 56 kilometers through the foothills of Bhutan and Sikkim to the state of West Bengal. As the region abruptly descends to the plains of the mainland, cultural, social and economic contrasts are strongly evident. There is an ongoing struggle by people trying to establish their right to autonomy, in most of the north-eastern states, which has led to political instability, strife and outright violence in the region. Strong inter-ethnic rivalries have aggravated the cycle of violence. In Assam, these resulted in the anti-foreigners movement that lasted for six long years, insurgency and of late, the Bodo Adivasi ethnic violence. In Manipur, as in other states in the North East, the movement for autonomy took violent turns. Army operations intensified the violence. Political unrest has created difficult conditions for the different communities in the region.

\section{Status of Women in North East India}

In north- east region, women enjoy greater mobility and visibility than women of other parts of the country. Practices such as dowry and bride burning are not very prevalent in the region. This is often cited to portray a picture of equity between men and women in the region and has given rise to the presumption that violence against women is not a major concern in the area. Data collected by the North East Network however suggests that violence against women, particularly domestic violence, is on the rise in the North-east. The rate of domestic violence in Assam is comparatively high than other states of north east India (The Law Research Institute, Guwahati).

\section{Objectives of the Study}

1. To conceptualize certain gender specific violation as Human Rights violation in context of North- East India.

2. To analyse various dimensions of violence against women and consequences of physical, mental and sexual violence faced by Women. 


\section{Methodology}

The prime issue before feminism is inequality. It helps us to analyze the social reality. The position of women in North- East India in the post-independence era is considerable. The role and status of women have undergone notable changes even in the urban areas as well as in rural areas. In this paper, an attempt has been made to examine the strategies to build a gender equitable society. The methodology of this paper is descriptive and required informations are collected from different secondary sources like books, research articles, different government documents etc.

\section{Violence against Women - A Conceptual Framework}

Violence against women is a manifestation of the historically unequal power relations between men and women, which have led to domination over and discrimination against women by men and to the prevention of women's full advancement (World Women's Conference, Beijing 1995). Both men and women face violence, an overwhelming majority of victims of sexual assault and domestic violence are women. Gender relations are skewed of the existence of patriarchy. In common parlance patriarchy means male domination. Religion has played an important role in creating and perpetuating patriachical ideology. While it is estimated that at least 3 out of every 5 women in India face domestic violence, reporting of such cases is extremely low. One of the major factors for this is the culture of silence (Report by The North East Network, 2004). Domestic violence is considered as a private matter and not to be interfered by others. Mentally harassment, sexual and psychological violence are not taken into account by a majority of women. Last few years, certain efforts have been made to bring consciousness among women that violation against women is a violation of women's human rights.

Witch- hunting has been increasingly highlighted in the last few years in north- east India. It is a belief of superstitions. Suspected women and men are branded as witches and are accused of causing harm to communities. These women and men are physically and mentally tortured. There is evidence of some being buried and even burnt alive. Control over resources, personal enmity with powerful members of the community and the prevalence of superstitions are some of the factors responsible for witch hunting. Several local and regional level organizations have been voicing their concerns and have been mobilizing members of the communities to build public opinion against such instances of violence against the superstitions.

\section{How patriarchy control over women}

Patriarchy control over women for a long period of time through a systematic process-

(a) The social system which believes that man is supporter to woman. Woman should be controlled by man and they are part of man's property.

(b) In patriarchical society man control woman's productivity both within the household and outside in paid work. Within the household women provides all kind of services to their families and in outside some women are excluded from better paid jobs and forced to sale their labour in low wages and head of the family selecively allow them for works.

(c) Men control also women's reproductive power. In many socities (such as Tribal Society) women do not have the freedom to decide how many children they want. Patriarchical society takes decision how many children they should have.

(d) Another area of women's subordination is control over women's sexuality. Women are obliged to provide sexual services to their husbands according to their needs and desires through the marriage system. Men also violate women's human rights through rape, threat of rape, forced prostitution etc.

Besides a woman may be deprived of her human rights on account of several non- gender related factors viz. caste or social backwardness, poverty or even religious and other cultural taboos.

\section{Types of Violence against Women}

Now-a-Days Violence affects the live of women and girls in all socio-economic classes around the world. It cuts across cultural and religious barriers and takes a variety of forms. Violence against women is largely unreported. Fear and stigma often prevent women from reporting incidents of violence or seeking assistance. In fact, 80 percent of women who have been physically abused by their partners have never informed the Police, NGOs or shelters.

Various types of violence which are discussed briefly as under-

\section{Drug Related Violence}

Alcoholism increases domestic violence against women and interruption takes place in the family. An alcoholic beats his wife and children. There are number of poor incidences has been occurred in the society. Besides husband who used illicit drugs, he also disturbed his family and spends his money without planning and he depends on his wife. Women (who are engaged in different paid works) are not allowed to have at least some money that they can spend as per their wish. 


\section{Sexual Violence}

In most of the cases the victim is branded as a woman of loose morals. Rape is viewed as a crime against the honour of not just the girl who is rape but also her family. Sometimes the nature of rape and the silence that tends to surround it makes it a particularly difficult human rights violation to investigate. Sexual violence has increasingly been used as a tool of war in the north east region. Hence for a long time, most cases of sexual violence resulting from the armed conflict involved states. Krishna Devi's case (a 30 year old woman lived in Manipur) illustrate the use of sexual violence in armed conflict scenarios in north- east India (report by North- East Network). Men also violate women's human rights through rape, threat of rape, forced prostitution etc.

\section{Dowry Related Violence}

Past few tears, there have been increased dowry related violence in north- east India specially in Assam. For that, death by burning is often punishment for the poor, innocent girls who is unable to satisfy the greed of her husband and family in- laws or take the decision of suicide for dowry related tortures.

\section{Domestic Violence}

Domestic violence is one of the greatest obstacles to gender equality. It obstructs women to secure their fundamental rights to equal protection under the law and the right to life and liberty. Domestic violence is violence that occurs within the private sphere, generally between individuals who are related through intimacy, blood or law. It can take the form of mental, physical or sexual violence. It reflects the unequal treatment meted out to women in the areas of health, education and income. Due to the patriarchal structure of society, women have been relegated to a subordinate position.

\section{Harassment at Work Place}

Most of the women are engaged in different manual works and most of them are ill- paid, but do not leave the job due to increasing unemployment. Harassment at work place is all pervasive. Sometime they are not secured at their work place and face new challenges.

\section{Women in Arm Conflict Situation}

North-east region has been witness to an ongoing low-intensity conflict for a long period of time. While the entire region continues to suffer, women living in such conditions are most vulnerable due to the restrictions on their mobility, the limited access to health services and most importantly, the lack of opportunities for education, employment and even leisure. Women have been, in internal war, the targets of sustained and frequently brutal violence committed by both parties of armed conflict. Both the sides often use violence to punish or dominate women believed to be sympathetic to the opposite side. Women have been threatened, raped and murdered during the conflict. (Human Rights Watch 1998).

During to arm conflict situation, women managed households. Becase the earner of the familly have either fled, been killed or joined the ranks of the underground. Thus, women who were till then not allowed to join the formal economic sectors are suddenly left on their own and are forced to eke out a living for themselves and their families. They are however not provided with any kind of support or alternate sources of livelihood. Nor are any avenues of employment made available to them. Here, unemploment may be considered as a major problem. NEN team found that often women have to resort to selling liquor, drugs or even prostitution to make enough money to run their household. North- East Netwok Report(2004) focused that often women have to resort to selling liquor, drugs or even prostitution to make enough money to run their household. The have lost their rights such as right to life, right to liberty and security etc.

Due to lack of awarness, illiteracy, lack of interaction, unequal access to information and other economic and non- economic resources, women plays triples role, women's rights can be violated.

\section{Suggestions}

Here are some suggestions for the protection of women's rights and elimination of violence of women's human rights -

1. An important requirment for bringing about empowerment of women attitude should be changed in both men and women. The feeling that women are meant for houehold activities and bearing children needs. It should be replaced by a feeling of equal partnership of women and men.

2. The women should be encouraged to organised themselves such as women's group, self- help group, N.G.O's etc. It can be effecttively used as instruments to mobised the women. Some successful women's organisations can also act as catalytic agents for encouraging women's participation in social and political activities. The government should provide financial support and infrastructure to some of the successful women's organisations to take of the responsibility to safeguards the women's rights and to create awarness amongst women, thereby eliminating poerful men taking advantage of the ignorance of women and controlling their decisions. 
3. National Literacy Mission and other organisations engaged in the Sarva Shiksha Abhiyan should also be assigned the responsibility of educating the rural women and men regarding the significance of Human Rights and empowermen of women. On the other hand, both print as well as electronic media can play a vital role in restructuring the rural society. It can act as an agent of political socialisation for inculcating the values of gendr equality and gender justice.

4. As soon as the Government of India and all State Governments of North- East India must make an all out effort to find a political solution to the armed conflict in north - east India. And the Armed Forces (Special Powers) Act must be repealed immediately. Armed forces misused this act and involved in violtion of human rights in many cases. Therefore, section 19 of the Human Rights Act 1993 must be suitably amended to make the verdict of Human Rights Commissions more binding. Restrictions on the Commission's jurisdiction over armed forces must be removed(Human Rights Act,1993).

5. National Human Rights Commission should knock at the doors of the offenders. Cases should not be pending in never ending process Strict action should be taken in this regard.

6. It is very essential to promote research works concerning violation of women's rights and human rights.

Government of India has enacted some laws for protection of women's rights such as

1. Protection of Women from Domestic Violence Act, 2005.

2. Amendment Proposed in Immoral Traffic (Prevention) Act 2005.

3. Dowry Prohibition Act, 1961.

4. The Commission of Sati (Prevention) Act and rules.

5. National Commission for Women Act.

\section{Conclusion}

Women status mainly depends on their rights and privileges and the roles assigned to them. Status is determined in terms of socio- economic indicators such as income, property, education and skills that open up opportunities of employment. One can not hope gender equity unless women have a share in the decision making process in the family and in the public sphere. When women raise their voices against underground oppression, they branded as state agents are silenced (MEN Report, 2005). With the recent introduction of courses on human rights and peace reconstruction there is evidence of regional women's groups calling on larger human rights organizations to address their grievances and local problems. They have also started reaching out to state agencies for redressal and justice.

\begin{tabular}{|c|c|c|}
\hline & & References \\
\hline [1]. & $\begin{array}{l}\text { R. Goswami, M.G. Sreekala } \\
\text { and M. Goswami, }\end{array}$ & $\begin{array}{l}\text { 'Women in armed conflict situations in India: Baseline } \\
\text { Report,' North East Network ,2008. }\end{array}$ \\
\hline$[2]$. & Vinod Sharma & Human Rights, A Global Phenomenon \\
\hline [2] & Nisha Garg \& & \\
\hline & Pradeep Kumar & $\begin{array}{l}\text { 'Women's Human rights and the Feminist Movement in } \\
\text { India: Some Issues', Journal of Politics, An Annual } \\
\text { Publication of the Department of Political Science, } \\
\text { Dibrugarh University, Vol. III, December, } 1996 .\end{array}$ \\
\hline$[4]$. & $\begin{array}{l}\text { Jean Dreze \& } \\
\text { Amartya Sen }\end{array}$ & $\begin{array}{l}\text { Gender Inequalty and Women's Agency, } \\
\text { Manoranjan Mohanty(ed), Class, Caste, Gender }\end{array}$ \\
\hline & & Sage Publications, 2004. P- 338-387 \\
\hline$[5]$. & Human Rights Watch & $\begin{array}{l}\text { Global Reports on Women's Human Rights. Delhi: } \\
\text { Oxfort University Press, } 1998\end{array}$ \\
\hline$[6]$. & North East Network: & $\begin{array}{l}\text { Women in Armed Conflict Situations, Delhi: North } \\
\text { East Network, } 2005\end{array}$ \\
\hline$[7]$. & Asian Centre for Human Rights & $\begin{array}{l}\text { India Human Rights Report, New Delhi: Asian Centre } \\
\text { or Human Rights, } 2009\end{array}$ \\
\hline [8]. & Kikon, Dolly & $\begin{array}{l}\text { 'Experiences of Naga Women in Armed Conflict', } \\
\text { Wiscomp Perspectives, 11, } 2004\end{array}$ \\
\hline [9]. & United Nations & $\begin{array}{c}\text { Violence Against Women, its Causes and Consequences, } \\
\text { United Nations, } 1994\end{array}$ \\
\hline
\end{tabular}

